\title{
Marshall's Influence on Swedish Economic Thought
}

Bo Sandelin (Bo.Sandelin@economics.gu.se)

\begin{abstract}
Alfred Marshall was by no means ignored, but his influence on Swedish economic thought at the end of the 19th and beginning of the 20th century was limited. On the general level, science and culture in Sweden were more dependent on the German-language countries. In a small country like Sweden, where there were only two chairs in economics in 1900, and eight in 1940, a few individuals embodied the development of the discipline. Knut Wicksell's theory of value and capital was mainly influenced by Jevons, Menger, Walras and, especially, Böhm-Bawerk. Gustav Cassel was inspired especially by Walras, but preferred Marshall to Böhm-Bawerk. There are not many references to Marshall in Heckscher's writings, but there may have been an indirect influence. Myrdal was well aware of Marshall's positions, but Marshall does not seem to have been an especially important source of inspiration. Marshall's Principles and Economics of Industry can be found in students' reading lists at Swedish universities during the first decades of the 20th century, often as optional literature.
\end{abstract}

Keywords: Marshall; Sweden; Wicksell; Cassel; Heckscher; Myrdal

JEL-Codes: B13; B20; B31

11 pages, January 3, 2006 


\section{Marshall's influence on Swedish economic thought}

Bo Sandelin*

Göteborg University

At the end of the 19th and beginning of the 20th centuries, science and culture in Sweden were most dependent on the German-language countries. From the 1880s through the 1910s, half of the foreign economics books bought by Swedish university libraries were published in Germany, while only a fourth were published in Britain or the USA. Doctoral theses in economics were written in Swedish or German; the first in English was in 1929. Thus, although Alfred Marshall (1842-1924) was by no means ignored, there was hardly a massive and direct early inflow of his thought into Sweden. He had a place among others on reading lists for economics courses at Swedish universities at the beginning of the 20th century, but none of his books was ever translated into Swedish.

As an individual economist, Marshall played a role, however. He was included in the references or cited in the footnotes in $68 \%$ of the Swedish doctoral theses in economics during 1895-1926. Knut Wicksell and Gustav Cassel were mentioned in slightly fewer, though with a larger number of works per thesis. During 1927-1949 Marshall was cited in $45 \%$ of the economics theses, more than any other foreigner, though surpassed (in order of importance) by the domestic economists Erik Lindahl, Knut Wicksell, Gunnar Myrdal, Gustav Cassel, and Bertil Ohlin (Sandelin 2001). In Myrdal's own thesis, Prisbildningsproblemet och föränderligheten (1927), Marshall played a more important role than in earlier Swedish theses, which may be indicative of the gradual shift from German and Austrian to Anglo-Saxon influence.

In a small country like Sweden, where there were only two chairs in economics in 1900, and eight in 1940, a few individuals embodied the development of the discipline. Wicksell introduced neoclassical thought to Sweden, followed - in an anti-marginal-utility version - by Cassel. Let us see who influenced them, as well as Eli Heckscher and Gunnar Myrdal, focusing especially on the role of Marshall. We will not scrutinize individual economists after those four, because as Marshall's thought increasingly constituted a large part of mainstream economics, his influence became more indirect, spread by authors who might not even know the original source.

\footnotetext{
* I am grateful to Rolf Henriksson, Lars Jonung, and Rick Wicks for valuable comments.
} 


\section{Knut Wicksell and the founders of neoclassicism}

Wicksell's first book, Value, Capital and Rent, whose original German edition was published in 1893, was mainly influenced by Böhm-Bawerk but also by Jevons and Walras, as is evident from the preface and a preparatory work (Wicksell 1892), as well as from the actual analysis in the book. Wicksell seems to have read Marshall's Principles (published in 1890) so late that he was not able to let the book play any significant role, though he added a couple of comments on Marshall more or less in passing. Thus he says in a footnote in the introduction that 'Marshall's Principles of Economics, which is based throughout on recent investigations, was, when this book was written, not yet published.'

In publications after Value, Capital and Rent, Wicksell refers incidentally to Marshall, but doesn't build his main analysis on him. In Finanztheoretische Untersuchungen (1896) he mentions, for instance, that Marshall had treated the principle of marginal-cost pricing, and in Interest and Prices (1898) he comments on details in Marshall's monetary ideas. Some authors (Boianovsky and Trautwein 2001, Smith 2004) have noticed that Wicksell characterizes Marshall's contribution to the English Gold and Silver Commission of 1887-88 as 'the most valuable contribution towards a solution' of the question 'how it was possible at the present stage of economic development for the quantity of the gold in the banks, or anywhere else, to exert an influence on prices; and how, in particular, the surplus of gold possessed at that time by the banks and the prevailing low rates of discount could be compatible in the light of the Quantity Theory with the falling level of prices' (Wicksell [1898] 1936, p. 76).

Yet Wicksell's assessment of Marshall's contribution was only relative for, although 'England's most distinguished monetary theorists and practitioners were summoned before the commission', Wicksell had 'not been able to discover that this fundamental question received any solution worthy of the name'. And he criticizes Marshall for laying 'too much emphasis on the direct influence that he alleges is exerted by the magnitude of banking reserves on the rate of interest and consequently on prices' (Wicksell [1898] 1936, p. 76).

In the first volume of Wicksell's Lectures on Political Economy (1901), Marshall continued to play a subordinate role. Wicksell comments on a few details in Marshall's Principles, but he gives more credit to the founders of the 'new ... theory of exchange' (p. 28), i.e., Menger, Jevons, and Walras, and especially concerning capital theory - Böhm-Bawerk. In the second volume (1906), Marshall is not even mentioned, but there is a reference to the English Gold and Silver Commission (p. 127). 
Böhm-Bawerk remained more influential on Wicksell than was Marshall. Wicksell's own writings suggest this, but also in the Wicksell archive at Lund University Library, 40 letters from Böhm-Bawerk to Wicksell are preserved, whereas only a few from Marshall. Wicksell and Marshall did correspond a bit in 1904-05, elicited by a comment by Cassel about Marshall's view on BöhmBawerk's interpretation of Turgot. Wicksell thought that Marshall had misinterpreted Böhm-Bawerk on the increased productivity of lengthening the period of procuction, though he also thought that Böhm-Bawerk's interpretation of Marshall's theory of waiting was wrong (Groenewegen 1995, pp. 473-475; the letters are printed in Gårdlund 1996).

After giving a lecture at the Royal Economic Society in London in 1906 on 'The influence of the rate of interest on prices' (where Marshall was not present), Wicksell apparently tried to continue correspondence with Marshall, but without much success (noted by Carl G. Uhr in his introduction to the fifth Swedish edition of Wicksell's Lectures).

\section{Gustav Cassel}

Gustav Cassel was early convinced of his own capability and grandeur, recounting in his memoirs how 'unsatisfactory and almost ridiculous' he found the teaching in Tübingen, Germany, which he attended in the summer of 1898. 'During these weeks, my decision to abolish the whole theory of value and build up an economic theory directly on a study of price formation came to maturity', he concludes (Cassel 1940, p. 15).

His first attempt was his long essay 'Grundriss einer elementaren Preislehre' (1899). Although Marshall is mentioned several times, this was not a work in the Marshallian tradition. Instead, it reminds more of Walras's general equilibrium analysis, which Cassel acknowledges in the introduction: 'Among the authors, who in a way should be regarded as my forerunners, I will here only mention Walras' (p. 396). Nor does Marshall appear prominent in Das Recht auf den vollen Arbeitsertrag (1900), which mainly reviews the literature in the field. Similarly, in The Nature and Necessity of Interest (1903), the handful of references to Marshall do not indicate more than that Cassel probably preferred Marshall to Böhm-Bawerk.

A concept like marginal utility was important for Marshall, but an abomination to Cassel. In his mature work, The Theory of Social Economy ([1918] 1932), Cassel says that, from the beginning of his study of economics, he felt 'that it ought to be possible to do away with the whole of the old theory of value as an independent chapter of economics and build up a science from the 
beginning on the theory of prices' (p. vii). Marshall would not play an important role in his approach, as Cassel makes clear in the main text: In pursuing our study of pricing, we deviate almost entirely from the path which the customary method takes' (p. 169). Cassel sees Marshall as the foremost representative of the latter, and thus indicates here the chief difference between his approach and Marshall's.

Cassel comes back to this in his memoirs, where he recounts meeting Marshall in 1901: 'I learnt to hold both him personally and his work in high esteem, and I understood that the economic system I wanted to build first of all must be confronted with the Marshallian system. It was, however, not easy to get any detailed conversations with Marshall. His time was severely occupied, and his health imposed certain restrictions on him. He could at a lunch make an exceptionally fruitful conversation of general character, but it was impossible to go deeper into a topic. He must have complete stillness for his digestion' (Cassel 1940, p. 39-40).

Marshall seems to have thought that he should have given Cassel more time. On the 18th of June, 1901, he wrote to Cassel: 'Now that I have said adieu, I feel how much more I should have liked to talk to you about, how many questions I should have liked to ask you as to your continental experience. But I am over-driven. During the last three months I have only given five lectures and I had reckoned on having about 50 days net for my own work. But interruptions, which are always numerous, have been so heavy, that in three months I have done less of my own work than in an uninterrupted three days. Family affairs have occupied me somewhat; but for the greater part I have busied with the concerns of other students of economics of all ages from 20 to 50; and my own work makes no progress. I feel very guilty towards you; I wish very much I could put myself more at your service and had enjoyed and profited by your delightful and energizing conversation more than I have. Yours very sincerely Alfred Marshall' (quoted in Cassel 1940, p. 40).

\section{Eli Heckscher - economic historian}

The bulk of Eli Heckscher's scholarly work was in economic history, though this would not exclude influence from Marshall. Carlson (1994, p. 15) sums up the view of several students of Heckscher: "The persons usually held to have been specially important for Heckscher's development are his teachers, the historian Harald Hjärne and the economist David Davidson, along with philosophers and economists such as John Stuart Mill, Alfred Marshall, and Knut Wicksell.' 
Heckscher set his hope on Marshall in a 1906 article about the general importance of the communication system for economic development. The literature in the field is weak, he complains, and the reason is to a large part 'the well-known difficulty, or rather impossibility, to demonstrate the importance of a single factor in a total development.' 'Maybe, one cannot indulge in expectations on a real profound treatment of the subject before Marshall's Principles reach the treatment of international trade and the location of industries between the countries.'

In the introduction to his doctoral dissertation about the significance of railways,Till belysning af järnvägarnas betydelse för Sveriges ekonomiska utveckling (1907), Heckscher again mentions Marshall, but also William Cunningham. The question of the effect of one factor in a society is absurd, he says, because 'the real relationship between most social phenomena is not cause and effect, but interaction, reciprocal dependence' (p. 1). This is one of Marshall's fundamental ideas in his Principles, Heckscher adds in a footnote, but it is difficult to find traces of Marshall in the rest of the text. In fact Olsson (1992, p. 52) argues that there 'are no signs of theory or hints of the problématique in the dissertation. Its character is more one of statistical description'.

Much later, in his introduction to the English edition of Mercantilism (1935), Heckscher states that Marshall's Principles 'was not only the startingpoint of my theoretical studies, but also profoundly influenced my approach to economic history'.

These seemingly contradictory observations raise the question of what kind of influence Marshall had on Heckscher. It seems to have been mostly of a general character, for Marshall was one of the foremost suppliers of economic theory when Heckscher was young. Heckscher pondered the relation between economics and history, and pleaded for the use of economic theory to explain economic history. Olsson (1992) points to similarities between Marshall's and Heckscher's views on Ricardo, on the younger historical school and sociology, and to their common lack of interest in scientific-philosophical questions; but those similarities were not reflected in explicit references in Heckscher's work.

\section{Gunnar Myrdal}

With his doctoral dissertation Prisbildningsproblemet och föränderligheten (1927) in mind, Gunnar Myrdal says in his quasi-memoirs Against the Stream: Critical Essays on Economics (1973) that his writings until the end of the 1920s 'had been in the great neoclassical tradition of economics'. But it was not primarily Marshall's version that he had adopted. Instead, like Cassel, he had built on 
Walras, in particular trying to introduce 'anticipations into the Walras model' (Myrdal 1973, p. 6).

Marshall was one of several economists who played a secondary though not unimportant role in Myrdal's dissertation; Cassel, Clark, and Knight were others. Myrdal discusses the relationship between statics and dynamics in Marshall and Cassel (pp. 25-27); mentions, not uncritically, Marshall's concept of the 'representative firm' (p. 112); refers, with assent, to Marshall's 'personal risks' and 'trade risks' (p. 138); argues against Marshall's view on insurance costs (p. 153); and compares his own view with Marshall's concerning the course of time, the experience of an individual firm, and the result of a whole trade (p. 185). On the whole, Myrdal was knowledgeable about Marshall and other main characters, and made comments on, and comparisons with, their writings when it made sense to do so, while remaining fairly independent.

Marshall played a similar role in Myrdal's very special book on the history of economic thought, The Political Element in the Development of Economic Theory (1930), which contains about a dozen comments on Marshall. In some cases Myrdal just mentions Marshall's attitude, in others it is possible to discern approval, and in still others Myrdal is critical.

For instance, Myrdal says that early economists, because of lack of data and for other reasons, were not much concerned with concrete problems, but from the later years of John Stuart Mill onwards, 'most economists endeavoured to make their theory more concrete. Marshall was the chief proponent of this ambition' (p. 9).

Myrdal criticizes Marshall's interpretation of Ricardo's theory of value, saying that Marshall's 'credulity drove him to new extremes'. He not only 'obscured Ricardo's arguments', but 'interpreted Ricardo and read views into him which Ricardo had never held nor could have held' (p. 78).

Similarly, Myrdal opines that the 'great treatises on welfare economics by Sidgwick, Marshall, Pigou, and Cannan are largely vain attempts to put into a system arguments which, by their nature, cannot be systematized' (p. 127).

There are also a few examples where Myrdal gives Marshall credit. Thus, 'the controversy between the subjective theory of cost and the theory of utility ... can be considered as settled, in principle, by Marshall's dictum about the two blades of a pair of scissors' (p. 82).

To sum up, Myrdal was well aware of Marshall's positions, but Marshall does not seem to have been an especially important source of inspiration. In Myrdal's later writings, when he considered himself an institutionalist, Marshall meant even less. 


\section{Marshall in early Swedish teaching}

Both Wicksell's Lectures on Political Economy and Cassel's The Theory of Social Economy were textbooks which also contributed to the development of economic theory, which is why they are remembered. In 1911 Sven Brisman published a more elementary textbook, Nationalekonomi., in which Marshall was missing in the review of literature; only Swedish books and books translated into Swedish were mentioned. In 1916 Brisman published the first edition of a more extensive book with the same name, in which Marshall is still not mentioned in any of the reviews of international and domestic literature that introduce each chapter, but only in a final section on 'general literature', where Joseph Shield Nicholson's Principles of Politcal Economy is considered the best of the more comprehensive works. Then Brisman declares: 'Beside this one, we notice Marshall's work Principles of Economics, which is probably the most famous one among the economic works that deal with the fundamental economic questions, and there is hardly any work of this kind that can compete with this one when it comes to descriptive power and interesting ideas. However, it is mainly restricted to the purely theoretical field, and it suffers from a certain lack of concentration. It is full of telling and interesting observations, but it investigates hardly any problem thoroughly, and it is therefore not an appropriate basis for individual study' (Brisman 1916, p. 267).

Did students have to read anything by Marshall? Marshall's Principles of Economics and Economics of Industry appeared on the reading lists for the economics courses at Swedish universities in the early 20th century. According to the Studiehandbok (student's manual) for 1904, the basic course in Lund, where Wicksell was professor, included works by Gide, Wicksell himself, Nasse, Scharling, Goschen, Leffler, Bücher and Herkner. The student should also choose among works by Helfferich, Webb, Marshall, and Böhm-Bawerk. However, some of these specific readings could be replaced by 'a more comprehensive textbook', of which Marshall's Principles is one option. By 1930 this option remains.

According to the Studiehandbok for 1904 in Uppsala, where David Davidson was professor, Marshall played a more prominent role, as his Economics of Industry was included in the basic course along with part of Wicksell's Lectures and articles by various authors. Economics of Industry remained on the list in 1920, when both volumes of Wicksell's Lectures were also included in full. 
The reading list in Stockholm under Cassel was very flexible. The Studiehandbok of 1908 required one work by Sundbärg plus four books chosen in a certain way among more than thirty, including Marshall's Economics of Industry. It remained in that position twenty years later.

In Gothenburg, Gustaf Steffen was the first professor of economics and sociology from 1903 to 1929 . In 1890 he had written an enthusiastic report of Jevons's theory of value, but should himself be regarded as an economist of the historical school. Nevertheless, the reading list he prepared for his students for the basic degree included, among other things, Wicksell's Lectures. For the honours degree another 17 books were required, including Marshall's Principles and Böhm-Bawerk's Positive Theorie des Kapitals (Lönnroth 1998, p. 269).

Thus some economics students during this period, but not all, were probably acquainted with some of Marshall's work.

\section{Conclusion}

During the decades around 1900, the German-language area had the most important cultural and scientific influence on Sweden. Swedish economists from Wicksell to the Stockholm School and beyond - also leaned more to macroeconomic questions than did Marshall, who devoted more attention to the theory of the firm, industrial organization and other microeconomic questions that were not central for the Swedes.

So, although Marshall's Principles of Economics and Economics of Industry could be found in the large reading lists at the Swedish universities during the first decades of the 20th century — often as optional books — he played a relatively modest role in this early period of modern economics in Sweden, compared to his ultimate international significance for the discipline.

Wicksell had been impressed especially with Böhm-Bawerk's but also with Jevon's and Walras's thought before he read Marshall's Principles, and thus Böhm-Bawerk meant more to Wicksell's theory of value and capital, although Wicksell and Marshall had a "common language" in their mathematical background, which Böhm-Bawerk did not possess. ${ }^{1}$ Concerning monetary theory, which was hardly Marshall's main area, Marshall was one among many whom Wicksell noticed.

Nor did the main points in Cassel's thought come from Marshall. Cassel's basic approach was general equilibrium, inspired by Walras, while partial equilibrium meant more to Marshall. Furthermore, Cassel saw no sense

\footnotetext{
${ }^{1}$ Marshall blamed Böhm-Bawerk for making mathematical mistakes 'for which a schoolboy of 12 would be punished' (Marshall quoted in Groenewegen 1995, p. 476). Cf, 'A boy in a village school who made such a blunder in his arithmetic would be punished', in a letter printed in Gårdlund (1996, p. 342).
} 
in the concept of marginal utility — or utility at all — while it was important in Marshall's analysis.

With the next generation of Swedish economists - Heckscher, then Myrdal and others - the influence from the German-language area was diluted, while Anglo-Saxon influence grew. As time went on, the number of important economists that researchers should be aware of increased, and much of Marshall's thought was also included in Swedish mainstream economics without reference to the original source, although occasional citations of specific points continued.

\section{References}

Brisman, Sven $(1911,1916)$, Nationalekonomi, Stockholm: P.A. Norstedt \& Söner.

Boianovsky, Mauro and Hans-Michael Trautwein (2001), 'An early manuscript by Knut Wicksell on the Bank Rate of Interest', History of Political Economy, Vol. 33, No. 3, pp. 485-507.

Carson, Benny (1994), The State as a Monster. Gustav Cassel and Eli Heckscher on the Role and Growth of the State, Lanham: University Press of America.

Cassel, Gustav (1899), 'Grundriss einer elementaren Preislehre', Zeitschrift für die gesamte Staatswissenschaft, Heft 3, pp. 395-458.

Cassel, Gustav (1900), Das Recht auf den vollen Arbeitsertrag, Göttingen: Vandenhoeck \& Ruprecht.

Cassel, Gustav (1903), The Nature and Necessity of Interest, London: MacMillan.

Cassel, Gustav ([1918], revised English translation 1932), The Theory of Social Economy, New York: Harcourt, Brace \& Company.

Cassel, Gustav (1940), I förnuftets tjänst, Vol. 1, Stockholm: Natur och Kultur.

Gårdlund, Torsten (1996), The Life of Knut Wicksell, Cheltenham: Edward Elgar.

Groenewegen, Peter (1995), A Soaring Eagle: Alfred Marshall 1842-1924, Aldershot: Edward Elgar.

Heckscher, Eli F. (1906), 'Kommunikationsväsendets betydelse i det nittonde århundradets ekonomiska utveckling', Ekonomisk Tidskrift, Vol. 8, pp. 293-320.

Heckscher, Eli F. (1907), Till belysning af järnvägarnas betydelse för Sveriges ekonomiska utveckling, Stockholm: Centraltryckeriet. 
Lönnroth, Johan (1998), 'Gustaf Steffen', in Warren J. Samuels (general editor), European Economists of the Early 20th Century, Vol. 1: Studies of Neglected Thinkers of Belgium, France, The Netherlands and Scandinavia, Cheltenham and Northhamton: Edward Elgar, pp. 263-282.

Marshall, Alfred (1890), Principles of Economics, London: Macmillan.

Marshall, Alfred and Mary Paley Marshall (1879), The Economics of Industry, London: Macmillan.

Myrdal, Gunnar (1927), Prisbildningsproblemet och föränderligheten, Uppsala och Stockholm: Almqvist \& Wiksells Förlag.

Myrdal, Gunnar ([1930] 1953), The Political Element in the Development of Economic Theory, London: Routledge \& Kegan Paul.

Myrdal, Gunnar (1973), Against the Stream: Critical Essays on Economics, New York: Pantheon Books.

Olsson, Carl-Axel (1992), 'Eli Heckscher and the Problem of Synthesis', Scandinavian Economic History Review, Vol. 11, No. 3, pp. 29-52.

Sandelin, Bo (2001), 'The De-Germanization of Swedish Economics', History of Political Economy, Vol. 33, No. 3, pp. 517-539.

Smith, Matthew (2004), 'Thomas Tooke's legacy to monetary economics', in Tony Aspromourgos and John Lodewijks (eds), History and Political Economy: Essays in Honour of P. D. Groenewegen, London and New York: Routledge, pp. 57-75.

Studiehandbok för de studerande inom juridiska fakulteten vid universitetet $i$ Lund (1904), Lund: Berlingska Boktryckeriet.

Studiehandbok för de studerande inom juridiska fakulteten vid universitetet $i$ Lund (1930), Lund: Grahns Boktryckeri.

Studiehandbok för de studerande inom juridiska fakulteten vid universitetet $i$ Uppsala (1904), Uppsala: Almqvist \& Wiksells Boktryckeri.

Studiehandbok för de studerande inom juridiska fakulteten vid universitetet $i$ Uppsala (1920), Uppsala: Almqvist \& Wiksells Boktryckeri.

Studiehandbok för de studerande inom den stats- och rättsvetenskapliga fakulteten vid Stockholms högskola (1908), Uppsala: Almqvist \& Wiksells Boktryckeri.

Studiehandbok för de studerande inom den stats- och rättsvetenskapliga fakulteten vid Stockholms högskola (1928), Uppsala: Almqvist \& Wiksells Boktryckeri. 
Wicksell, Knut (1892), 'Kapitalzins und Arbeitslohn', Jahrbücher für Nationalökonomie und Statistik, pp. 852-874.

Wicksell, Knut ([1893] 1954), Value, Capital and Rent, London: George Allen \& Unwin.

Wicksell, Knut (1896), Finanztheoretische Untersuchungen nebst Darstellung und Kritik des Steuerwesens Schweden, Jena: Verlag von Gustav Fischer.

Wicksell, Knut ([1898] 1936), Interest and Prices, London: Macmillan.

Wicksell, Knut ([1901] 1934), Lectures on Political Economy, Vol. 1, London: George Routledge \& Sons.

Wicksell, Knut ([1906] 1935), Lectures on Political Economy, Vol. II, London: George Routledge \& Sons. 